\title{
PERANAN PEMERINTAH DALAM MENDORONG PERTUMBUHAN BANK SYARIAH
}

\author{
Ishak Trianda \\ (Dosen STEI SEBI) \\ Email: ishak_trianda@yahoo.com
}

\begin{abstract}
Abstrak
Pemerintah Indonesia sebagai motor penggerak pembangunan nasional. Sudah saatnya melakukan planning ke depan untuk menjadikan Indonesia sebagai pusat sentral ekonomi syariah dunia. Untuk itu perlu akselerasi daya saing industri ekonomi syariah nasional. Diawali dengan menyiapkan anggaran yang significan untuk sosialisasi terhadap perangkat-perangkat pendukung yang membuat bangkit dan berkembangnya ekonomi syariah tersebut khususnya perbankan syariah. Diantaranya menyiapkan sumber daya manusia yang handal diperkirakan kedepan membutuhkan 200 ribu tenaga kerja baru untuk keuangan dan perbankan syariah, menyiapkan angggaran sosialisasi terhadap sekitar $85 \%$ penduduk Indonesia yang beragama Islam ( 240 juta jiwa) calon pengguna dan pemanfaat industri keuangan perbankan syariah tanah air. Termasuk keseluruh pesantren di 33 propinsi Indonesia ( 25 ribu pesanteren), pada 3,7 juta santri dan sejumlah kelompok usaha mikro syariah dan BMT. Diharapkan nantinya menjadi penopang pembangunan nasional agar mampu membangun pondasi ekonomi yang kuat, regulasi, persaingan industri yang sehat, pelaku industri modern, teknologi tepat guna sehingga menopang efisiensi industri. Sehingga pada saatnya menjadikan Indonesia sebagai motor penggerak ekonomi syariah dunia melampaui Arab Saudi, Iran dan Malaysia. Sangat memungkinkan, karena saat ini juga perkembangan ekonomi syariah Indonesia terus tumbuh mencapai $40 \%$ setiap tahun dibandingkan pertumbuhan ekonomi konvensional hanya $19 \%$. Bahkan saat ini Indonesiapun dapat disebut negara dengan industri keuangan syariah terbesar di dunia karena memiliki lebih 20 ribu buah koperasi syariah dan Balai Mandiri Syariah Terpadu.
\end{abstract}

Kata kunci : Sentral Ekonomi Syariah, Akselerasi, Sosialisasi

\begin{abstract}
Indonesian government as a driving force of national development. It is time to do the planning ahead to make Indonesia as the central hub of Islamic finance world. It is necessary to accelerate the competitiveness of the national industry of Islamic finance. Begins with setting up a budget that significan to disseminate the devices that make up and support the development of Islamic economics is particularly Islamic banking. Among prepare qualified human resources estimated future need 200 thousand new workers for the Islamic banking and finance, preparing budget socialization of around $85 \%$ of Indonesia's population is Muslim (240 million) of potential users and beneficiaries of Islamic Banking industry country. Including schools in 33 provinces throughout Indonesia (25 thousand pesanteren), at 3.7 million students and a number of Islamic micro business group and BMT.
\end{abstract}


Expected later became the backbone of national development in order to be able to build a strong economic foundation, regulatory, industry competition is healthy, modern industry, appropriate technologies that support the efficiency of the industry. So that in time to make Indonesia as the Islamic world's economic powerhouse surpassed Saudi Arabia, Iran and Malaysia. It is possible, because today the development of Islamic finance Indonesia continues to grow at $40 \%$ per year compared to conventional economic growth is only 19\%. Even today Indonesia to be called the country with the largest Islamic finance industry in the world because it has more than 20 thousand pieces and cooperative Islamic Syariah Mandiri Integrated Hall.

Key words : Center Shari'a Economi, Accelerate, Sosialization

\section{Pendahuluan}

Berkenaan dengan hal tersebut makalah ini diupayakan merancang langkah-langkah strategis menjadikan Indonesia sebagai pusat keuangan perbankan syariah dunia. Untuk itu ada beberapa langkah yang perlu dilakukan pemerintah, diantaranya harus menyediakan anggaran dana untuk sosialisasi kepada penduduk Indonesia. Dimana untuk penduduk muslimnya saja mencapai 240 juta jiwa dan kalau berdampak maslahat dan positip maka umat non muslim akan mengikuti langkah-langkah umat Islam dalam penggunaan bank syariah.

Sosialisasi juga dilakukan kepada kabupaten/kota di seluruh Indonesia. Dimana didalamnya terdapat 25 ribu pesantren dan 71 ribu madrasah diluar pesantren. Disamping mempersiapkan SDM yang handal karena diperkirakan ke depan dibutuhkan lebih dari 200 ribu tenaga kerja baru untuk keuangan dan perbankan syariah.

Kenapa perlu anggaran yang sicnifican untuk sosialisasi kepada pilar-pilar penopang ekonomi Islam tersebut karena jumlah penduduk muslim Indonesia merupakan jumlah penduduk muslim terbesar di dunia. Begitu juga dengan jumlah madrasah dan pesantren termasuk yang sicnifican untuk Asia Tenggara. Jadi apabila pemerintah bisa menyampaikan informasi yang baik dan mampu memberdayakan pilarpilar yang ada hal ini akan berdampak positip dalam pertumbuhan dan perkembangan perbankan dan keuangan syariah. Sehingga nantinya akan menjadi multiplier effek terhadap langkah-langkah menjadikan Indonesia pusat episentrum perbankan dan keuangan syariah dunia.

\section{Metodologi}

\subsection{Kerangka Pemikiran}

Tidak bisa dipungkiri di dalam sejarah bahwa sistem ekonomi orde baru yang sudah berjalan lebih dari 30 tahun tidak mampu menahan tsunami resesi moneter dari Negara Amerika yang melanda dunia tahun 
1997 mampu merusak ekonomi Asia Tenggara terutama Indonesia. Sejarah telah mencatat kerisis moneter kita waktu itu 1 dolar USA mencapai 15000 rupiah. Pemerintah kita benar-benar mengalami kesulitan. Bagaimana cara untuk menormalkan kerisis ekonomi waktu itu . Ternyata sistem yang dibangun tidak begitu ampuh untuk membentengi serangan kerisis moneter dari luar.

Beberapa bank kon vensional waktu itu mengalami kollaps dan membuat pemerintah Indonesia harus memberikan suntikan dana yang cukup besar untuk mengantisipasi anjloknya keuangan perbankan Indonesia. Namun disisi lain ternyata ada yang membuat kita gembira saat itu. Karena bank-bank yang sudah menerapkan sistem syariah tidak mengalami krisis sebagaimana bank konvensional waktu itu. Ternyata bank-bank yang telah menerapkan sistem syariah tetap mampu bertahan menghadapi kerisis ekonomi yang melumpuhkan perbankan konvensional.

Beberapa tahun setelah kerisis ekonomi 1998, strategi ketahanan keuangan Indonesia mulai ditata dengan memasyarakatkan sistem lembaga keuangan mikro (LKM) dimasyarakat, hal ini dimulai dengan pembicaraan topic keuangan mikro oleh para pakar antara lain; Martowijoyo (2002), Syukur (2002) dan Budiartono dan Sumodiningrat (2003), dimana momentum pembahasan LKM senantiasa terkait dengan upaya penanggulangan kemiskinan.

Sebaiknya untuk kita orang beriman berekonomi dengan sistem syariah adalah pilihan, karena bermanfaat sangat besar terhadap kehidupan manusia. Umat Islam bisa menjalankan agamanya dalam bidang ekonomi, yang pada gilirannya mengiringi pada pengamalan Islam secara kaffah, sehingga tidak muncul dikotomi syariah yakni beribadah secara Islam tetapi bermuamalah secara kapitalis. Disamping itu dengan menerapkan dan mengamalkan sistem ekonomi syariah kita mendapatkan keuntungan yaitu duniawi dan ukhrowi. Keuntungan duniawinya adalah bagi hasil sedangkan ukhrowinya berupa pahala ibadah melalui pengamalan syariah Islam dan terhindar dari dosa riba.

Dampak lainnya bila kita memanfaatkan jasa perbankan syariah berarti kita memajukan ekonomi Islam lewat lembaga keuangan syariah, karena umat Islam berupaya mengentaskan kemiskinan umat dan meningkatkan kualitas ekonomi kerakyatan. Dan yang terpenting kalau menabung di lembaga keuangan syariah akan mendapat berkah sebagaimana sabda nabi SAW : "Tiga macam yang mendapat berkah ", 1 . Mudhorobah, 2. Jual beli secara cicil, 3. Mencampur gandum basah dan kering untuk dimakan sendiri bukan untuk dijual. Dan sistem inilah sesungguhnya yang lebih banyak digunakan perbankan syariah pada decade itu sehingga ketahanan ekonomi dimasyarakat jauh lebih kuat karena telah memberdayakan beberapa LKM bersama BMT yang banyak berdirinya diprakarsai swasta, lembaga swadaya masyarakat. Dimana LKMS dan BMT berfungsi sebagai intermediasi dalam aktivitas suatu perekonomian. 
Dengan modal pengalaman kekuatan ekonomi diatas perbankan syariah terus laju dan berkembang. Sektor perbankan syariah terus mengalami peningkatan yang significan selama lima tahun terahir. Asset perbankan syariah yang terdiri dari Bank Umum Syariah (BUS), Unit Usaha Syariah (UUS) dan Bank Perkreditan Rakyat Syariah (BPRS) hingga oktober 2012 meningkat menjadi Rp. 179 triliun atau tumbuh sekita 37 persen disbanding oktober 2011 sebesar Rp. 125,5 triliun.

Dengan data diatas membuat perbankan syariah Indonesia menjadi keempat terbesar setelah Iran, Malaysia, dan Arab Saudi. Walaupun disisi lain pangsa perbankan syariah terhadap industri perbankan nasional relatif masih lebih kecil, sekitar empat - lima persen dari total industri. Begitu pula pangsa perbankan syariah gelobal hanya sebesar 0,7 persen dari industri perbankan global.

Di sisi lain ada peluang yang cukup besar dalam pengembangan industry perbankan syariah, diprediksi akan lebih berkembang di Indonesia mengingat lebih dari 85 persen dari 245 juta penduduk Indonesia adalah muslim. Dimana pada tubuh ummat Islam ada jaringan pesantren pada 33 propinsi mempunyai 25 ribu pesantren yang memiliki 3,7 juta santri dan sejumlah BMT ditambah 71 ribu madrasah tersebar diseluruh Indonesia mulai dari $\mathrm{Ra}, \mathrm{Mi}$, Mts dan Ma.

Perkembangan perbankan syariah tanah air cukup pesat sehingga nantinya membutuhkan sumber daya manusia yang memadai dan mempunyai potensi pada perbankan syariah. Pemerintah telah mengeluarkan undang-undang no.10 Th 1998 tentang perubahan undangundang no.7 Th 1992 mengenai perbankan. Dikeluarkannya fatwa bunga bank haram oleh MUI Th. 2003 banyak bank yang menjalankan perinsip operasionalnya pada sistem syariah.

Banyak bank konvensional membuka cabang syariah dan mendirikan BPR syariah, ada juga yang melakukan konversi dari perinsip konvensional menjadi syariah. Hal ini terjadi karena bank-bank syariah mempunyai keunggulan dalam mengatasi kerisis ekonomi Th. 1998 yang lalu karena memiliki potensi pasar yang cukup besar. Kita mengetahui jumlah terbesar penduduk Indonesia adalah muslim dan masih banyak yang berhubungan dengan bank konvensional yang menggunakan sistem riba (bunga). Pengembangan perbankan syariah tanah air harus terus menerus dilaksanakan karena telah diatur oleh Undang-undang no. $10 \mathrm{Th}$ 1998 tentang perbankan syariah.

\subsection{Data Dan Sumber Data}

Makalah ini dikembangkan dari sebagian informasi tulisan-tulisan pakar ekonomi dan penasehat khusus presiden bidang ekuin \& pembangunan pada harian Republika, ditambah dengan tulisan penulis sendiri yang dimuat di buku “Apbd Islami, adakah ?” (Islamisasi filosofis 
\& sistem Apbd) pada tahun 2012, juga tulisan jurnal para pakar di beberapa website.

Jadi jenis data yang dikumpulkan adalah jenis Library Reasearch. Dan penganalisaan data secara garis besar dilakukan secara deskriptif kwalitatif. Untuk membedah atau mengarahakan agar Indonesia bisa menjadi kekuatan ekonomi keuangan dan perbankan syariah dunia, maka dilakukan pendekatan pada aspek kekuatan (strengthen), kelemahan (Weaknesses), peluang (Oppurtunity) dan ancaman (Threat) atau disingkat SWOT.

\section{HASIL PEMBAHASAN}

\subsection{Eksitensi Perbankan Syariah Indonesia}

Industri Perbankan syariah dengan dukungan program yang jelas hanya dari Bank Indonesia mengalami perkembangan yang luar biasa setelah hampir 15 tahun berlakunya UU perbankan syariah tersebut. Sehingga saat ini total asset perbankan syariah telah mencapai 200 triliun rupiah, telah jauh melampaui total assetnya yang di bawah 5 triliun pada 15 tahun lalu. Sehingga saat ini industry perbankan syariah sudah memiliki layanan kantor 3000 unit yang telah menyerap tenaga kerja sekitar 30 ribu orang.

Perlu kita support langkah-langkah pemerintah dalam beberapa tahun terahir mulai menjalankan perannya, sejalan dengan pernyataan Presiden SBY bahwa perbankan syariah merupakan agenda nasional pada festival Ekonomi Syariah tahun 2008. Waalaupun pada awalnya belum ada tindak lanjut yang jelas dari kementriannya.

Gubernur BI yang baru Agus Martowardoyo saat menjalani uji kepatutan di gedung DPR RI menyampaikan akan menjadikan Indonesia sebagai pusat keuangan \& perbankan syariah dunia. Begitu juga dengan pernyataan bapak Dahlan Iskan Menneg BUMN pada harian Republika 3 maret yang lalu sedang mengkaji kemungkinan konversi bank BUMN menjadi bank syariah. Pernyataan gubernur BI dan Menneg BUMN ini sangat beralasan karena Indonesia memiliki banyak kekayaan, dan Industri perbankan syariah kita sedang dilirik Negara-negara investor asing. Sehingga peran yang dilakukan pemerintah ini diharapkan jadi titik awal era baru perbankan syariah tanah air.

Pada tanggal 26-27 Februari 2013 telah diselenggarakan The 12 th Annual Islamic Finance Summit di London sebagai bentuk legitimasi eksistensi ekonomi Islam di dunia. Ternyata asset keuangan syariah global pada 2011 mencapai 1,36 triliun dolar AS atau tumbuh 103 persen dari 639 miliar dollar AS pada tahun sebelumnya. Disamping informasi tersebut ternyata perkembangan ekonomi syariah Indonesia terus meningkat mencapai rata-rata 40 persen setiap tahunnya dibandingkan pertumbuhan ekonomi convensional yang hanya sebesar 19 persen, 
bahkan saat ini Negara Indonesia disebut-sebut sebagai Negara dengan industry keuangan syariah terbesar di dunia dengan 22 ribu gerai koperasi syariah dan balai mandiri syariah.

Selain itu data lain yang menggembirakan dimana sector perbankan syariah Indonesia terus mengalami peningkatan yang sicnifican selama 5 tahun terahir, dimana asset perbankan syariah yang terdiri dari Bank Umum Syariah (BUS), Unit Usaha Syariah (UUS) dan bank perkreditan rakyat syariah (BPRS) hingga oktober 2012 meningkat menjadi Rp.179 triliun atau tumbuh sekitar 37 persen disbanding oktober 2011 sebesar 125,5 triliun. Dengan fenomena ini membuat perbankan syariah Indonesia membuat perbankan syariah Indonesia menjadi keempat terbesar setelah Iran, Malaysia dan arab Saudi. Namun demikian pangsa perbankan syariah terhadap industry perbankan nasional relatif masih kecil, sekitar $4-5$ persen dari total industry, begitu juga pangsa perbankan syariah global hanya sebesar 0,7 .

Data lainnya yang menggembirakan dimana peraktek perbankan syariah Indonesia menunujukkan kinerja yang cukup baik disbanding perbankan konvensional. Dimana fungsi intermediasi, pengumpulan dana pihak ketiga dan pembiayaan kemasyarakat pada perbankan syariah masing-masing mencapai Rp. 97,8 triliun dan Rp. 92,8 Triliun dengan tingkat financing deposit ratio (FDR) sebesar 95,7 persen.

Sementara data pada bank konvensional, loan to deposit rationya hanya mencapai $60-70$ persen. Besarnya aliran dana dari perbankan syariah ke sector riil ini sangat menunjang terhadap percepatan pembangunan dan distribusi pertumbuhan keseluruh wilayah Indonesia. Industri keuangan dan perbankan syariah diproyeksikan akan semakin berkembang di Indonesia, bahkan berdampak positip terhadap pertumbuhan keuangan dan perbankan syariah dunia.

Untuk itu Indonesia perlu perlu menyiapkan anggaran APBN 2014 bila perlu Indonesia minta bantuan ke IDB (Islamic Development Bank). Dana tersebut akan digunakan untuk mensosialisasikan ke 85 persen penduduk muslim Indonesia atau sekitar 240 juta jiwa beragama Islam. Dimana penduduk muslim Indonesia adalah jumlah populasi penduduk muslim terbesar dunia. Ditubuhnya terdapat 25 ribuan pesantren yang tersebar di 33 provinsi tanah air, jumlah santrinya diperkirakan 3,7 juta. Dan ada 71 ribu madrasah di Indonesia mulai dari RA, MIN/MIS, MTSN/MTSS, MAN/MAS. Dan beberapa jaringan BMT yang merupakan faktor pendukung ekonomi syariah Indonesia. Hal ini akan berdampak kepada percepatan penopang pembangunan nasional nantinya. Dan secara tidak langsung akan berefek kepada munculnya titik epicentrum keuangan syariah dunia di Indonesia. Pemerintah tidak ada ruginya dalam mengeluarkan anggaran tersebut melalui APBN, karena sosialisasi tersebut akan berdampak multiflier effek terhadap perkembangan dan pertumbuhan perbankan syariah kita di kawasan Asia dan dunia. 


\subsection{Persfektif Perbankan Syariah Dan Keuangan Dunia}

Selama ini permasalahan gerakan ekonomi Islam hanya tertumpu pada dua teori besar, yaitu larangan riba dan perintah membayar zakat dan termasuk di dalamnya infak dan sedekah. Hal tersebut memang selalu diungkap oleh ayat Al-Qur'an dan Hadist Nabi. Implementasi dari dua teori besar tersebut adalah, yang pertama dari ada larangan riba maka muncul dan berkembangnya perbankan syari'ah (di Indonesia berdirinya bank Muamalah) lalu disusul beberapa bank-bank syariah lainnya. Sedangkan implementasi dari perintah membayar zakat dimulai dari gerakan sadar membayar zakat (GSZ) yang ditindak lanjuti dengan perumusan UU No.38 tahun 1999 tentang tentang pengelolaan zakat. Dan pada akhirnya muncul lembaga Amil Zakat (LAZ) di masyarakat dan Badan Amil Zakat (BAZ) di kalangan Instansi.

Dari kedua gerakan besar ekonomi Islam tersebut ternyata masih sangat lemah produksinya dan belum menjadi kekuatan gerakan ekonomi ummat di tanah air. Dari berbagai penelitian awal menunjukkan bahwa bank syariah diharapkan mampu menjadi alternatip sistem perbankan nasional yang sedang mengalami kerisis dari banyak hal. Namun bila diukur dari partisipasi ummat Islam Indonesia yang jumlahnya lebih dari 200 juta jiwa itu. Namun asset yang dimiliki sampai tahun 2012 memang mampu mencapai 179 triliun tapi bank syariah tersebut masih dianggap bank kelas bawah disbanding bank konvensional yang ada.

Sedangkan implementasi dari gerakan besar kedua yakni gerakan sadar zakat oleh lembaga maupun badan amil zakat. Ternyata juga zakat belum memjadi solusi pengentasan kemiskinan di tanah air yang di derita ummat. Tetapi menolong fakir miskin dalam skala kecil zakat mampu menolong fakir miskin dan lain-lain.

Terlepas belum maksimalnya dampak positip kerja perbankan syariah dan badan amil zakat, tetapi keduanya menjadi harapan besar ummat bagi kebangkitan ekonomi Islam untuk masa mendatang selama pengelolaannya dilakukan secara benar dan professional. Namun sebaiknya jangan hanya terpaku pada kedua permasalahan besar diatas. Sebaiknya peranan pemerintah sangat diharapkan harus menggali instrument-instrumen ekonomi Islam lainnya yang sangat potensial. Diantaranya BMT, Asuransi Syariah, Gadai Syariah, Pasar Modal serta Wakaf Produktif dan Wakaf Tunai.

Kalau kita lihat perkembangan instrument ekonomi Islam tersebut memang cukup menggembirakan seperti BMT (Baitul Mal Wattamwil) lembaga keuangan mikro ini sampai sekarang ini sudah mencapai 4000 buah jumlahnya. Asuransi syariah yang sudah berdiri sejak tahun 1994 dengan berdirinya PT Asuransi Takaful Indonesia, maka sejak itu jasa-jasa asuransi yang dikembangkan dengan perinsip syariah terus bertambah sehingga sekarang sudah mencapai 45 lembaga asuransi syariah, dimana yang 42 buah adalah perusahaan asuransi syariah 
sedangkan 3 buah lainnya adalah perusahaan Reasuransi Syariah. Perkembangan pegadaian syariah Indonesia juga menunjukkan tingkat perkembangan yang baik. Bahkan sampai saat ini jumlah pembiayaan mencapai lebih 1,6 triliun dengan jumlah kantor cabang berjumlah 120 buah. Perkembangan yang menggembirakan juga terjadi di pasar modal. Berdasarkan keputusan nomor: Kep-523/BI/2010 tentang daftar efek syariah telah ditetapkan daftar-daftar efek yang telah sesuai dengan syariah berjumlah 209 yang terdiri dari SBSN (Surat Berharga Syariah Nasional), saham, obligasi syariah dan reksadana syariah. Khusus dalam permasalahan ini pemerintah telah mengeluarkan sukuk Negara sebagai salah satu instrumen pembiayaan pemerintah, yaitu sukuk global, korporasi dan sukuk ritel . Bahkan sekarang setelah diundangkannya UU No.19 tahun 2008 tentang SBSN . Hal ini memberi harapan di tengah APBN yang selalu deficit untuk bisa mendorong sumber keuangan alternative bagi Negara.

Disamping permasalahan diatas ada yang harus sangat dipotensikan oleh pemerintah yakni gerakan wakaf produktif . Sebenarnya ada dua hal tentang awakaf produktif, yaitu pertama; harta tetap (tidak bergerak) seperti tanah, rumah,took, dan harta tidak tetap (bergerak) seperti hewan, buku dan lain-lain. Dan kedua adalah wakaf produktif dalam artian wakaf uang.

Wakaf adalah salah satu ibadah yang bercorak ekonomi sosial dalam Islam selain zakat, infak dan sedekah. Bahkan di dalam sejarah pertama ummat Islam permasalahan wakaf ini sudah dimulai. Sejarah mencatat pada masa Umar Bin Khattab ada problem tanah produktif di Khaibar, sehingga Umar waktu itu bertanya kepada Rasul, "Wahai Rasulullah saya mendapatkan sebidang tanah yang cukup besar di Khaibar, suatu harta yang belum pernah kudapat sebelumnya lebih baik dari tanah itu, lalu apa yang hendak engkau perintahkan kepadaku ?". Rasul menjawab, "Jika engkau suka tahanlah bendanya dan sedekahkan hasilnya". (Hadist). Maka sejarahpun mencatat bahwa tanah Khaibar sangat subur dan produktif dan hasilnya dapat digunakan untuk kesejahteraan umat Islam. Berikutnya dalam sejarah wakaf menampilkan peran yang sangat potensial dalam meningkatkan kesejahteraan umat Islam dalam bidang ekonomi dan pendidikan. Sebagai contoh Universitas Al-Azhar di Mesir adalah dikelolal dan didanai dari tanah waqaf.

Oleh karena itu dalam upaya membangkitkan kembali salah satu pilar penopang ekonomi Islam ini pada dunia Islam. Indonesia perlu memberdayakan lahan-lahan kosong yang belum produktif karena hal ini ternyata di masa Turki Usmani termasuk hal yang digunakan untuk mengatasi kemiskinan. Berdasarkan data kementerian Agama jumlah tanah wakaf di Indonesia cukup banyak lebih dari 358.710 lokasi dengan luas 819.207.733.99 M2 dan belum termasuk jumlah yang belum terdaftar di daerah-daerah. Suatu hal sangat menarik apa yang disampaikan Syafi'I Antonio, bahwa dalam sebuah penelitian sampai abad 19 ternyata 75 persen lahan yang dapat ditanami semasa Khilafah Turki adalah tanah 
wakaf, $33 \%$ lahan di Tunisia, $50 \%$ lahan di Aljazair, $30 \%$ lahan di Iran (1930) dan 12,5 \% lahan di Mesir adalah tanah wakaf. Tanah-tanah tersebut diatasnya ditanami produk-produk unggulan, membangun real Estate dan pusat-pusat perbelanjaan. Sehingga harta wakaf itu dapat bernilai guna.

\subsection{Langkah-langkah Strategis Memajukan Perbankan Dan Keuangn Syariah}

Ada beberapa langkah atau strategi yang bisa dilakukan untuk mengangkat nilai perbankan dan Keuang syariah Indonesia agar berpotensi menjadi center perbankan dan Keuangan syariah di dunia. Secara operasional haruslah melalui tahapan-tahapan berikut ini :

1) Melakukan daya saing industri syariah secara nasional, termasuk di dalamnya termasuk melakukan percepatan pembukaan cabang-cabang maupun unit-unit bank syariah di seluruh Indonesia.

2) Menyiapkan anggaran yang cukup signifikan melalui APBN 2014 untuk sosialisasi terhadap perangkat-perangkat pendukung ekonomi syariah dan perbankan syariah secara nasiona ataupun terhadap perangkat pendukung lainnya seperti BMT, Asuransi Syariah, gadai Syariah, Pasar Modal Syariah dan Wakaf.

3) Mendorong dan mensuport keberadan Sekolah Tinggi Ekonomi Islam yang membuka kelas perbankan syariah dan Akuntansi syariah karena pada saatnya nanti kampus-kampus ini menjadi salah satu pilar penopang tegaknya peradaban Islam masa mendatang.

4) Menyiapkan sumber daya manusia yang handal karena diperkirakan kedepan membutuhkan tenaga kerja baru untuk keuangan dan perbankan syariah yang cukup banyak.

5) Mengangkat kementerian yang khusus menangani Wakaf yang terpisah dari kementrian agama, agar lebih fokus kerjanya karena ternyata lahan wakaf di Indonesia cukup sicnifican jumlahnya kalau ini dipotensikan akan mampu mengentaskan kemiskinan di tanah air. Tidak cukup sekedar Badan Wakaf saja seperti yang ada sekarang.

6) Memaksimalkan dengan baik Lembaga-lembaga zakat (LAZ) maupun Badan Amil Zakat (BAZ) Yang ada agar zakat itu sebenarnya sebuah potensi kekuatan umat Islam yang mampu mengentaskan kemiskinan. Sejarah pernah mencatat dimasa Khalifah Umar Bin Abdul Aziz ternyata tidak ada lagi rakyat yang tercatat sebagai penerima zakat karena rakyat yang miskin waktu itu diberdayakan melalui dana-dana zakat sehingga mencapai tingkat sejahtera, bahkan pendapatan ratarata perkapita penduduk waktu itu mencapai 40 juta/bulan. 
7) Untuk menjadikan Indonesia central keuangan dunia perlu memfasilitasi mahasiswa program S2 untuk melanjut ke jenjang S3. Bidang ekonomi Syariah maupu lainnya. Karena S3 Indonesia masih sangat sedikit hanya 14000 orang kalah jauah dengan jumlah S3 India dan Tiongkok 500000 orang. Apalagi disbanding dengan Jahudi pada setiap satu juta penduduk Jahudi ada 41000 bergelar S3 dibandingkan dengan kita pada setiap satu juta penduduk hanya mempunyai 47 orang S3.

8) Negara-negara Islam yang bergabung dalam OKI harus membentuk mata uang bersama agar mampu menguasai aktivitas perekonomian dunia. Karena selama ini yang menguasai aktivitas perekonomian dunia adalah mata uang dolar AS, EURO dan Yen Jepang. Bahkan secara keseluruhan dolar AS menguasai setiap bentuk aktivitas ekonomi dan transaksi keuangan nasional, mencapai 80 - 90 persen dari total transaksi.

9) Negara-negara yang tergabung dalam OKI perlu melakukan pasar bersama dan meningkatkan kerja sama ekonomi dunia Islam. Dan hal ini bisa dimulai dari beberapa kawasankawasan regional, seperti Asia Tenggara, Timur Tengah dan Afrika. Sangat aneh sebenarnya kalau saat ini perdagangan sesama Negara OKI hanya berjalan sekitar 12 persen saja dari total semua perdagangan Negara OKI, sementara total perdagangan OKI hanya 7 persen dari total perdagangan dunia. Pada hal jumlah sumber daya alam di dunia ini ada sekitar 60 persen dari Negara-negara OKI.

\section{KESIMPULAN DAN SARAN}

\subsection{Kesimpulan}

1) Perkembangan ekonomi syariah di Indonesia terus bertumbuh mencapai rata-rata 40 persen setiap tahunnya dibandingkan pertumbuhan ekonomi konvensional yang hanya sebesar 19 persen.

2) Khusus sector perbankan syariah Indonesia terus mengalami peningkatan yang sicnifican selama 5 tahun terakhir. Asset perbankan syariah yang terdiri atas Bank Umum Syariah (BUS), Unit Usaha Syariah (UUS) dan Bank Perkreditan Rakyat Syariah (BPRS) hingga oktober 2012 meningkat menjadi Rp.179 triliun atau tumbuh sekitar 37 persen disbanding oktober 2011 hanya sebesar Rp.125,5 triliun. Meskipun disbanding asset perbankan konvensional hal ini masih sangat kecil. 
3) Industri perbankan syariah sekarang jumlah kantor unit layanan sudah mencapai 3000 unit telah menyerap lebih dari 30 ribu tenaga kerja, bahkan ke depan diprediksi membutuhkan sekitar 200 ribu tenaga kerja baru untuk keuangan dan perbankan syariah.

4) Diprediksi Indonesia bisa menjadi center ekonomi dan keuangan syariah kedepan karena saat ini Indonesia disebutsebut beberapa kalangan sebagai industry keuangan syariah terbesar dunia karena memiliki 22 ribu gerai koperasi syariah dan Balai Mandiri Terpadu. Bahkan untuk kalangan perbankan syariah dunia Indonesia saat ini sudah termasuk empat besar setelah Iran, Malaysia dan Arab Saudi.

\subsection{Saran}

1) Dalam rangka menjadikan Indonesia center ekonomi Dunia pemerintah perlu menyiapkan anggaran APBN yang significan, akselerasi daya saing industry ekonomi syariah. Untuk itu semua pihak harus mendukung dalam membangun fondasi, regulasi, persaingan industry yang sehat, pelaku industry yang modern, serta penggunaan teknologi tepat guna untuk industry yang baik.

2) Keadaan sistem moneter dunia saat ini sangat tidak menguntungkan dunia Islam. Dunia Islam sangat membutuhkan reformasi terhadap sistem moneter yang ada karena kebanyakan Negara Islam masih dalam tahap sedang membangun, kebanyakan menginginkan sistem moneter yang lebih stabil dan adil bagi semua Negara. Untuk itu Indonesia sangat potensi untuk menggerakkan OKI dan IDB dalam rangka mendorong terbentuknya sistem perdagangan dan moneter yang dilandasi sebuah mata uang yang stabil dan lebih adil. 


\section{DAFTAR PUSTAKA}

Firmanzah. 15 Maret 2013. Potensi Industri Syariah. Artikel Opini Hal 4. Harian Republika.

Ishak Trianda. 2012. Apbd Islama Adakah : Islamisasi Filosofis Dan Sistem Apbd. Jakarta. Gema Insani Press.

Jaribal Bin Ahmad. 2006. Fikih Ekonomi Umar Bin Al-Khattab. Jakarta. Pustaka Al-Kautsar Group.

Martowijoyo, S. 2002. Dampak Pemberlakuan Sistem Bank Perkreditan Rakyat Terhadap Kinerja Lembaga Pedesaan. Artikel Th I - No.5. Jurnal Ekonomi Rakyat. www.ekonomirakyat.go.id

Rizqullah. 5 April 2013. Era Baru Bank Syariah. Artikel Opini Hal 4. Harian Republika.

Sofyan Syafri. 2007. Akuntansi Perbankan Syariah. Jakarta. LPTE Usakti.

Syukur, M. 2006. Membangun Lembaga Keuangan Mikro (LKM) Pertanian Yang Berkelanjutan : Sebuah Pengalaman Lapangan. Warta Prima Tani. Volume I Nomor 1. Balai Besar Pengkajian Dan Pengembangan Teknologi Pertanian. 